\title{
Inheritance of Human $\alpha_{1}$-Acid Glycoprotein (Orosomucoid) Variants
}

\author{
A. Myron Johnson, Karl Schmm, and Chester A. Alper with the tech- \\ nical assistance of LESLEY BISSETT \\ From the Blood Grouping Laboratory and the Department of Medicine, \\ Children's Hospital Medical Center, and the Departments of Medicine \\ and Pediatrics, Harvard Medical School, Boston, Massachusetts 02115, \\ and the Department of Biochemistry, Boston University School of \\ Medicine, Boston University Medical Center, Boston, Massachusetts 02118
}

\begin{abstract}
A B S T R A C T Although variants of sialic acid-free $\alpha_{1}$-acid glycoprotein have been described in human beings, the mode of inheritance of these types has not been reported previously. With the use of a new technique of immunofixation after agarose gel electrophoresis of neuraminidase-treated whole serum, the present study demonstrates that the types of $\alpha_{1}$-acid glycoprotein variants in family members are consistent with inheritance as autosomal traits with codominant expression. Gene frequencies have been determined for several ethnic groups. Of a total of 11 maternal-cord serum pairs, seven were discordant types, indicating that the fetus synthesizes $\alpha_{1}$-acid glycoprotein and confirming a previous report that there is no significant transplacental passage of this protein.
\end{abstract}

\section{INTRODUCTION}

Human $\alpha_{1}$-acid glycoprotein (1), or orosomucoid (2), has been shown to be heterogeneous in both the native and the sialic acid-free states. Polymorphism of the intact glycoprotein is manifested by a variable number of bands on starch-gel electrophoresis at $\mathrm{pH} 2.9$ (3). After removal of the sialyl residues by either enzymatic (4) or acid (5) hydrolysis, the variants are distinguished on starch-gel electrophoresis at $\mathrm{pH} 5.0$ by a major slow moving band, a major fast band, or both bands in equal concentration. These variants have been designated I, II, and III, respectively (4).

Twin studies (4) and the constancy of types within individuals $(6,7)$ have suggested a genetic basis for the $\alpha_{1}$-acid glycoprotein variants. The present investigation was undertaken, therefore, to evaluate the possibility of genetic transmission of variants within families. The

Received for publication 10 July 1969. types found in family members indicate that the variants are inherited as autosomal traits. In order to simplify genetic classification, it is proposed that the phenotypes be redesignated $\mathrm{SS}, \mathrm{FF}$, and $\mathrm{FS}$, corresponding to the slow, fast, and double electrophoretic patterns, respectively, and that the alleles be designated $\mathrm{Or}^{\mathrm{s}}$ and $\mathrm{Or}^{\mathrm{F}}$. This nomenclature is used in this report.

\section{METHODS}

Preparation of $\alpha_{1}$-acid glycoprotein. Highly purified $\alpha_{1}-$ acid glycoprotein was prepared by Mr. Thomas Boenisch of the Blood Grouping Laboratory as follows. Pooled human serum was precipitated with $0.2 \mathrm{M} \mathrm{HClO}$, at $0^{\circ} \mathrm{C}(8)$. The 1 resulting supernatant solution was neutralized and concentrated by ultrafiltration to approximately $3 \mathrm{~g}$ protein $/ 100 \mathrm{ml}$. Ammonium sulfate was added to give a concentration of $2.65 \mathrm{moles} / \mathrm{liter}$, and the $\mathrm{pH}$ was adjusted to 5.0 . Insoluble proteins were removed by centrifugation, and the supernatant solution was dialyzed exhaustively against tap water. After dialysis against $0.04 \mathrm{M}$ phosphate buffer, $\mathrm{pH}$ 5.8, the solution was applied to a diethylaminoethyl (DEAE)-Sephadex (A50) column equilibrated with this buffer and washed until the effluent was protein free. The $\alpha_{1}$-acid glycoprotein was then eluted with $1 \mathrm{M} \mathrm{NaCl}$, concentrated, dialyzed against $0.01 \mathrm{M}$ sodium citrate-citric acid buffer, $\mathrm{pH} 5.0$, applied to a similarly equilibrated carboxymethyl (CM)Sephadex (C50) column, and eluted with the latter buffer. The eluate was concentrated to $10 \mathrm{~g}$ protein $/ 100 \mathrm{ml}$ and examined by immunoelectrophoresis (9), using several different antisera against whole human serum, and by agarose electrophoreis (10). No impurities were detected.

Preparation of antiserum. $0.1 \mathrm{ml}$ of a $100 \mathrm{mg} / 100 \mathrm{ml}$ solution of neuraminidase type $\mathrm{V}$ from Clostridium perfringens $^{1}$ was added to $0.3 \mathrm{ml}$ of a $4 \mathrm{~g} / 100 \mathrm{ml}$ solution of the pure, pooled $\alpha_{1}$-acid glycoprotein. The digest was dialyzed at $28^{\circ} \mathrm{C}$ against $0.1 \mathrm{M}$ acetate buffer, $\mathrm{pH} 5.0$, for $72 \mathrm{hr}$. Aliquots of this solution were then diluted, emulsified with equal volumes of complete Freund's adjuvant, and injected

\footnotetext{
${ }^{1}$ The neuraminidase preparations used in the study were obtained from Sigma Chemical Co., St. Louis, Mo. -
} 


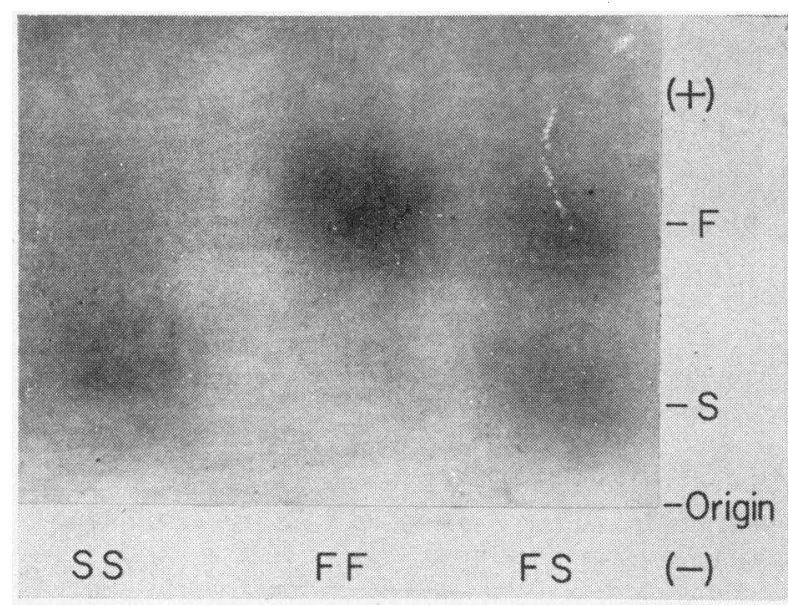

FIGURE 1 Appearance of human $\alpha_{1}$-acid glycoprotein variants as demonstrated by immunofixation after starch-gel electrophoresis of neuraminidase-treated whole serum. Separation was performed at $300 \mathrm{v}$ for $5 \mathrm{hr}$, using $0.02 \mathrm{M}$ acetate buffer, pH 5. The positions of the anode, the cathode, and the two major bands are indicated on the right.

into multiple subcutaneous and intradermal sites of three female New Zealand albino rabbits. Each rabbit was injected with $0.2 \mathrm{mg}$ of antigen three or four times at 2- to 3-wk intervals. Serum samples were obtained at weekly intervals beginning 2 wk after the last injection. The antiserum from all three rabbits was monospecific as determined by immunoelectrophoresis using pooled normal human serum as antigen. Only samples which showed a precipitin arc against normal human serum using antiserum dilutions of $1: 40$ or higher were used for this study.

Samples for typing. Serum or plasma samples from 214 individuals of 24 kindred, including 30 matings with children, were evaluated in the genetic study. Paired maternal-cord sera were those used in a previous study (11). Samples that

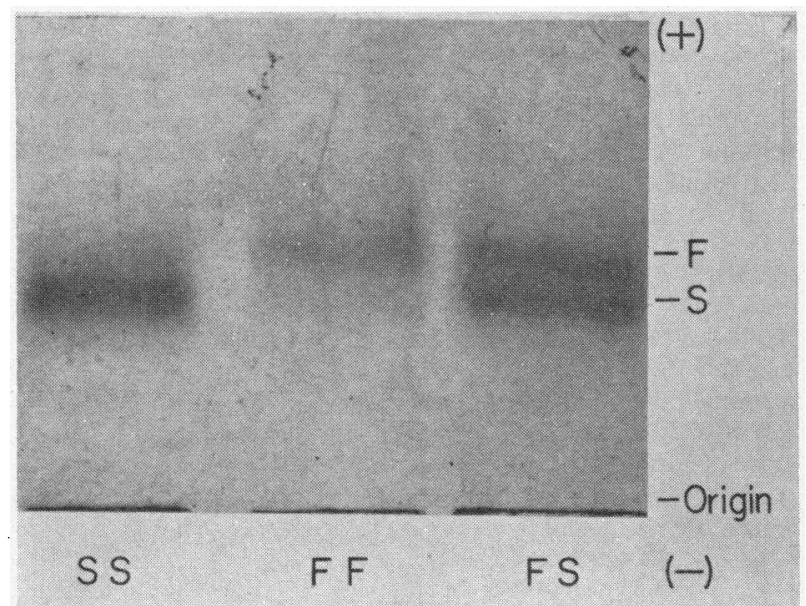

FIgURE 2 Patterns of $\alpha_{1}$-acid glycoprotein variants as shown by agarose electrophoresis of desialized whole serum, followed by immunofixation. Ionic strength 0.05 barbital buffer, $\mathrm{pH} 8.6$, with $0.0018 \mathrm{M}$ calcium lactate was used for the separation. had been frozen at $-20^{\circ}$ or $-80^{\circ} \mathrm{C}$ for up to $10 \mathrm{yr}$ were still readily typable. In addition to the family study, plasma samples from 18 disputed paternity cases were evaluated, but the results are not included in the family data.

Serum types of haptoglobin, transferrin, Gc-globulin, the third component of complement (C3), and Gm and Inv determinants of immunoglobulins were determined on the majority of sera. In addition, red cells were tested for the following antigens: $\mathrm{A}, \mathrm{A}_{1}, \mathrm{~B}, \mathrm{H}$; $\mathrm{Rh} 1,2.3,4,5,8 ; \mathrm{P}_{1}$; K1, 3, 4; $\mathrm{Le}^{\mathrm{a}}, \mathrm{Le}^{\mathrm{b}} ; \mathrm{M}, \mathrm{N}, \mathrm{S}, \mathrm{s} ; \mathrm{V}^{\mathrm{w}}, \mathrm{M}^{\mathrm{b}}, \mathrm{Lu}^{\mathrm{a}}, \mathrm{Fy}^{\mathrm{a}}, \mathrm{Jk}^{\mathrm{a}}$, and $\mathrm{Wr}^{\mathrm{a}}$. Except as noted, all typings were compatible with the stated family relationships.

Neuraminidase treatment of individual sera. Preliminary experiments showed that $30 \mu \mathrm{g}$ of type V or $2 \mu \mathrm{g}$ of type VI neuraminidase (Clostridium perfringens) per $100 \mu \mathrm{l}$ of serum and digestion for at least $24 \mathrm{hr}$ were required for essentially complete removal of the sialyl residues. Therefore, $50 \mu 1$ aliquots of serum and $10 \mu \mathrm{l}$ of a $10 \mathrm{mg} / 100 \mathrm{ml}$ solution $(1 \mu \mathrm{g})$ of type VI neuraminidase were placed in individual bags of 1 inch cellulose dialysis tubing. The samples were dialyzed against $0.15 \mathrm{~m}$ acetate buffer, $\mathrm{pH}$ 5.0, for $48 \mathrm{hr}$ at $28^{\circ}-30^{\circ} \mathrm{C}$. After incubation, the samples were transferred to small test tubes and stored at $-20^{\circ} \mathrm{C}$ until examined.

Electrophoresis. Electrophoretic separation was performed in $1 \mathrm{~mm}$ thick agarose gels (10), using barbital buffer, ionic strength $0.05, \mathrm{pH} 8.6$, containing $0.0018 \mathrm{M}$ calcium lactate (12). Separation was continued until hemoglobin A had migrated approximately 1 inch from the origin. For comparison with previous typing systems $(4,5)$, separation was also performed in horizontal starch gels (13), using $\mathrm{pH} 5.0$ acetate buffer.

Immunofixation. After electrophoresis, the expected area of migration of the neuraminidase-treated $\alpha_{1}$-acid glycoprotein was covered with the antiserum described above. Diffusion of antiserum into the agarose or previously sliced starch gels was permitted to take place for approximately $1 \mathrm{hr}$ in a moist chamber. Excess antiserum was rinsed off with saline, and the gels were washed and stained as previously described (14).

Antigen-antibody crossed electrophoresis. Initial electrophoretic separation of previously typed, desialized whole sera was performed in thin-layer agarose-acrylamide gels (15), using $0.05 \mathrm{~m}$ sodium acetate buffer, $\mathrm{pH}$ 5.0. The concentra-

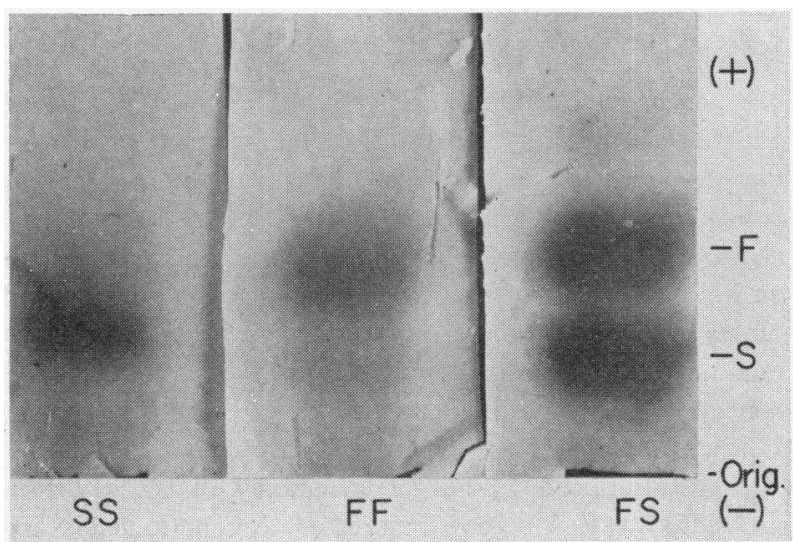

FIGURE $3 \alpha_{1}$-acid glycoprotein typing as performed by a previous technique. The partially purified protein, desialized by acid hydrolysis, was separated by starch-gel electrophoresis at $\mathrm{pH} 5$ and stained routinely. The minor anodal and cathodal bands are barely perceptible. 
tions of agarose and acrylamide were 0.8 and $5 \mathrm{~g} / 100 \mathrm{ml}$, respectively. After separation, strips of the gel were removed and transferred to an agarose gel, in $\mathrm{pH} 8.6$ barbital buffer, containing specific antiserum to $\alpha_{1}$-acid glycoprotein. Electrophoresis at right angles to the first separation was performed as described by Laurell (16).

Quantitations. Determination of $\alpha_{1}$-acid glycoprotein concentrations was performed by the electroimmunodiffusion technique of Laurell (17).

\section{RESULTS}

Determination of types. Neuraminidase-treated whole sera, developed by immunofixation after starch and agarose gel electrophoresis respectively, are shown in Figs. 1 and 2. For comparison, the $\alpha_{1}$-acid glycoprotein variants as demonstrated by a previous method (5) are shown in Fig. 3. The patterns are comparable and easily differentiable by all three techniques. Agarose gels were used for the remainder of the study because of relative simplicity of use.

As has been reported previously (4), sera of homozygous $S$ individuals have a small amount of protein which migrates identically with the $\mathrm{F}$ component, and

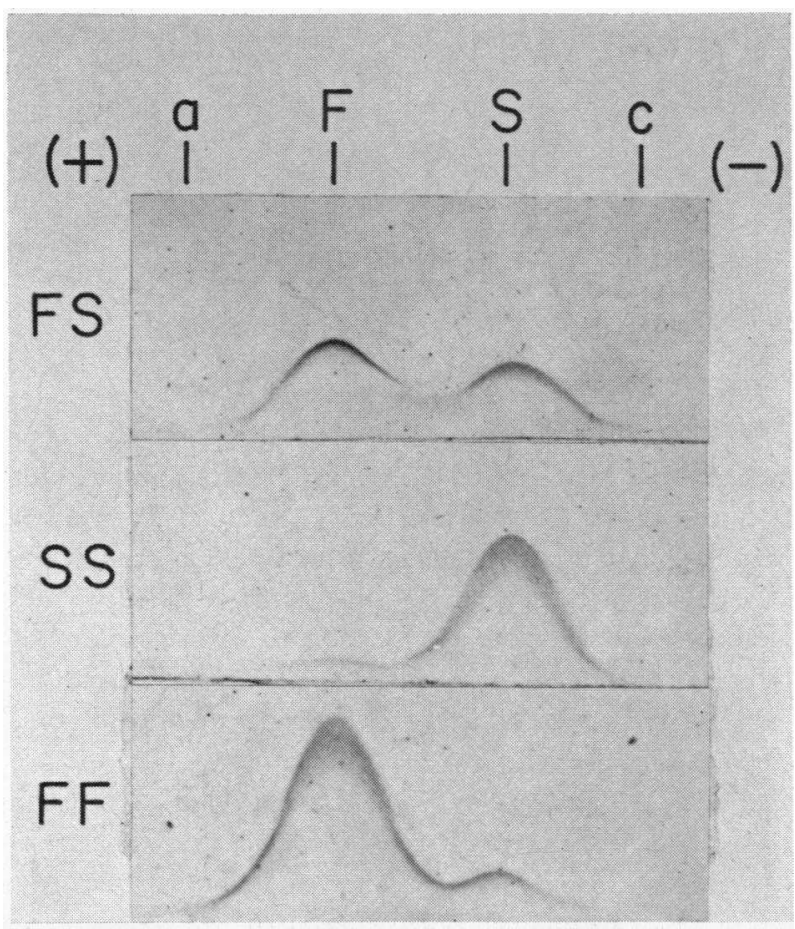

FIGURE 4 Antigen-antibody crossed electrophoresis of the three variants of $\alpha_{1}$-acid glycoprotein. The initial separations were performed in thin-layer agarose-acrylamide gels, using $0.05 \mathrm{M}$ acetate buffer, $\mathrm{pH}$ 5. The positions of the anode and cathode for the initial electrophoresis are noted at the top of the figure. The protein types are indicated at the left, and the positions of the peaks are shown at the top. The minor anodal and cathodal shoulders are designated $a$ and $c$, respectively.
TABLE I

Variants of $\alpha_{1}$-Acid Glycoprotein in Family Members

\begin{tabular}{|c|c|c|c|c|c|}
\hline \multicolumn{2}{|c|}{ Matings } & \multicolumn{3}{|c|}{$\begin{array}{l}\text { Observed types in } \\
\text { children }\end{array}$} & \multirow[b]{2}{*}{$\begin{array}{l}\text { Expected } \\
\text { ratios* }\end{array}$} \\
\hline Type & $\begin{array}{l}\text { Num- } \\
\text { ber }\end{array}$ & FF & FS & sS & \\
\hline$F F: F F$ & 3 & 19 & - & - & $1: 0: 0$ \\
\hline$F F: F S$ & 7 & 11 & 10 & - & $1: 1: 0$ \\
\hline $\mathrm{FF}: \mathrm{SS}$ & 2 & - & 11 & - & $0: 1: 0$ \\
\hline FS:FS & 12 & 13 & 23 & 9 & $1: 2: 1$ \\
\hline FS:SS & 3 & - & 9 & 6 & $0: 1: 1$ \\
\hline SS:SS & 2 & - & - & 13 & $0: 0: 1$ \\
\hline
\end{tabular}

* FF:FS:SS, assuming autosomal codominant inheritance of types.

vice versa. Most samples of all three types also show trace amounts that migrate in bands anodal to the fast (F) component and in a single band cathodal to the slow (S) component. Although these bands can be discerned on standard typing, they are more clearly demonstrated as small peaks or shoulders by antigen-antibody crossed electrophoresis (Fig. 4). The anodal bands have been shown to be the result of persisting sialyl residues (18). The faint cathodal band, like the two primary bands, is sialic acid-free $(18,19)$ and most likely represents a minor gene product, similar to those described for $\alpha_{1}$-antitrypsin (20) and C3 (12) and suggested for other proteins $(14,21-24)$.

\section{TABLE II}

$\alpha_{1}$-Acid Glycoprotein Types and Concentrations in Maternal-Cord Paired Sera

\begin{tabular}{|c|c|c|c|c|}
\hline \multirow[b]{2}{*}{$\begin{array}{c}\text { Pair } \\
\text { number }\end{array}$} & \multicolumn{2}{|c|}{$\begin{array}{c}\alpha_{1} \text {-acid glycoprotein } \\
\text { type }\end{array}$} & \multicolumn{2}{|c|}{ Concentration } \\
\hline & $\begin{array}{c}\text { Ma- } \\
\text { ternal }\end{array}$ & Cord & $\begin{array}{c}\text { Ma- } \\
\text { ternal }\end{array}$ & Cord \\
\hline & & & \multicolumn{2}{|c|}{$\mathrm{mg} / 100 \mathrm{ml}$} \\
\hline 1 & SS & SS, SS* & 47 & $9, f$ \\
\hline 2 & $\mathrm{FS}$ & SS\& & 53 & 15 \\
\hline 3 & FF & FS\& & 64 & 52 \\
\hline 4 & FF & FS\& & 15 & 13 \\
\hline 5 & SS & SS & 39 & 34 \\
\hline 6 & $\mathrm{FS}$ & $\mathrm{FS}$ & 53 & 25 \\
\hline 7 & FS & SS\$ & 55 & 8 \\
\hline 8 & FS & FS & $\ddagger$ & $\ddagger$ \\
\hline 9 & FS & $F F \&$ & 34 & 8 \\
\hline 10 & FF & $\mathrm{FS} \&$ & 41 & 38 \\
\hline 11 & FS & SS\& & 72 & 33 \\
\hline \multicolumn{3}{|c|}{ Mean concentrations\| } & 48 & 23 \\
\hline
\end{tabular}

\section{* Dizygous twins.}

$\$$ Discordant types.

$\ddagger$ Not determined.

|| Pooled normal_adult‘serum, $70 \mathrm{mg} / 100 \mathrm{ml}$.

Inheritance of $\alpha_{1}$-Acid Glycoprotein Variants 


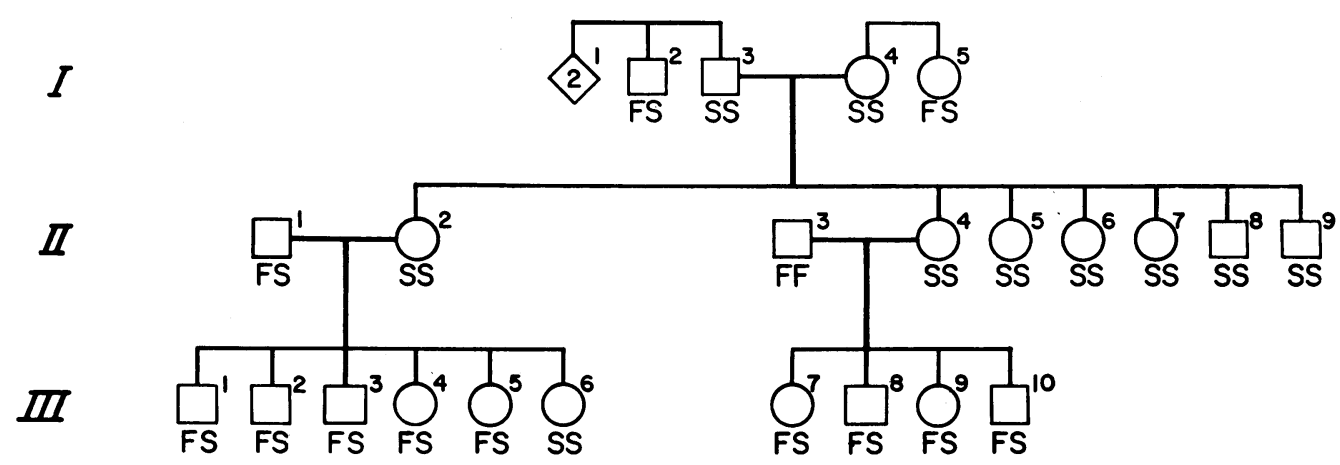

FIGURE 5 The genealogy of the Con family. Generations are designated by Roman numerals at the left, and individuals within a generation by Arabic numerals at the upper right of each circle (female) or square (male). An Arabic numeral within a diamond indicates the number of siblings not tested.

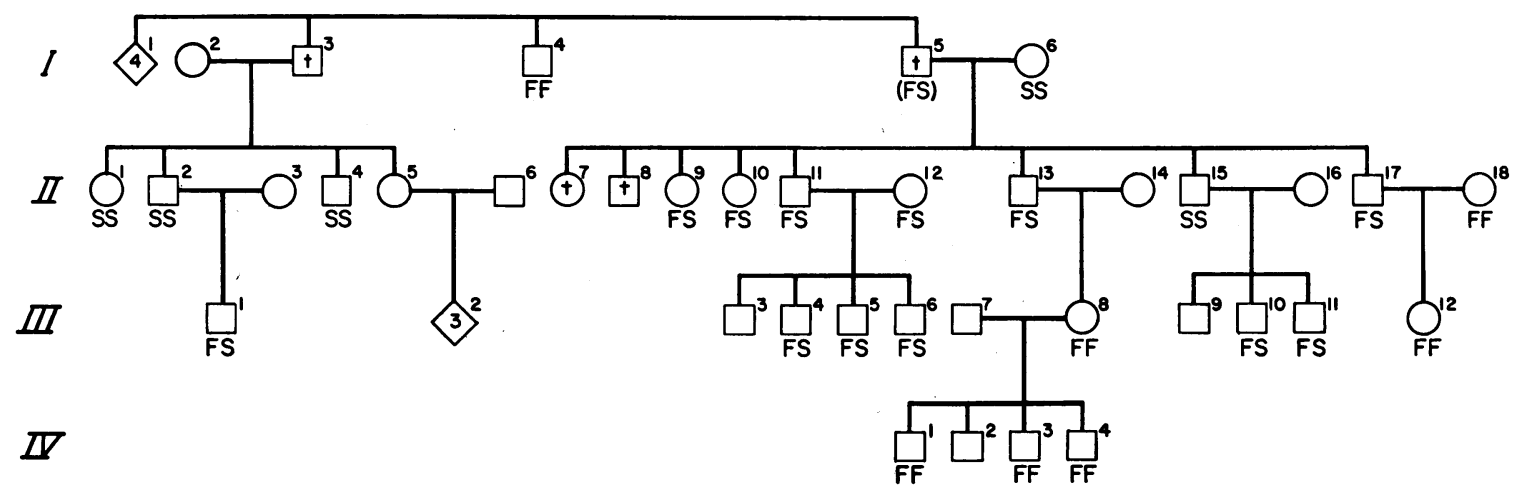

FIgURE 6 The Lap family. The presumed type of a deceased family member is given in parentheses; no types are given for the other individuals not tested. See Fig. 3 for explanation of the other symbols.

On antigen-antibody crossed electrophoresis, the more anodal protein, $F$, forms a higher precipitation peak than does the $\mathrm{S}$ protein. This phenomenon has also been noted with C3 (12) and $\alpha_{1}$-antitrypsin (25) and is felt to be the result of the difference in electrophoretic mobility. There is some variation among individual sera in the ratio of the $F$ and $S$ bands, but the types are still easily distinguishable in almost all instances.

Family studies. The pedigrees and $\alpha_{1}$-acid glycoprotein types of the Con and Lap families are shown in Figs. 5 and 6 , respectively. The pattern of inheritance of the three types is that of autosomal codominance, with equal gene expression in the heterozygous state, male as well as female heterozygotes, and male-to-male transmission.

The overall results of the family studies are summarized in Table I. Expected frequencies of types in children from each possible combination of parental types were calculated assuming Mendelian codominant inheritance. The observed types agree completely with this assumption.
Maternal-cord pairs. The $\alpha_{1}$-acid glycoprotein types and concentrations found in paired maternal-cord sera are shown in Table II. 7 of 12 infants, born of 11 mothers, had types different from the maternal types. The band ratios in these infants, as determined by antigen-antibody crossed electrophoresis, were similar to those in adults of the same types. The maternal and cord serum concentrations are in agreement with those reported by Laurell (26).

Twins. As noted in Table II, one pair of dizygous twins in the maternal-cord study had the same types. In addition, typings in 11 pairs of dizygous twins, six pairs of monozygous twins, and one set of trizygous triplets are summarized in Table III. The observed types are consistent with the proposed mode of inheritance, as were those in another study (4).

Questionable paternity cases. Of the 21 children examined, only two were found to have $\alpha_{1}$-acid glycoprotein types incompatible with those of the putative fathers, again assuming autosomal codominant inheritance. In 
TABLE III

Variants of $\alpha_{1}$-Acid Glycoprotein in Twins and Triplets

\begin{tabular}{ccc}
\hline & Parental types* & Offspring types \\
\hline Dizygous $\ddagger$ & FS:FS & FS,SS $\$$ \\
twins & FS:FS & FF,SS $~$ \\
& FS:FS & FS,FF $\$$ \\
& FS:FF & FS,FS and FF,FS $\$$ \\
& SS:FS & FS,FS \\
& FF:FF & FF,FF; FF,FF; FF,FF \\
& SS:SS & SS,SS \\
SS:FF & FS,FS \\
Trizygous $\ddagger$ & FS:FF & FS,FF,FF $~$ \\
triplets & & \\
Monozygous $\ddagger$ & FS:FS & FS,FS \\
twins & FS:FS & FS,FS \\
& FF:FF & FF,FF \\
& FS:FS & FF,FF \\
& SS:SS & SS,SS \\
& FF $: F F$ & FF,FF
\end{tabular}

* Father:mother.

$\ddagger Z$ ygosity as determined by sex, red cell antigens, and serum protein variant types.

$\S$ Discordant types. one instance, the man was definitely excluded as the father of the child on the basis of haptoglobin and Inv incompatabilities. In the other, the red cell and serum types were such that neither exclusion nor presumption of paternity was possible.

One mother and her child were found to have relative concentrations of the faster band intermediate between those seen in FS and SS individuals, both on routine typing and on antigen-antibody crossed electrophoresis. The patterns were most compatible with heterozygosity with a relative decrease in the $\mathrm{F}$ band reminiscent of the hyposynthetic variants described for Gc-globulin (14, $27,28)$, haptoglobin (29), and the third component of complement (30).

Gene frequencies. The $\alpha_{1}$-acid glycoprotein types found in individuals of several ethnic groups are given in Table IV. Most of these typings were performed by previous techniques. Gene frequencies were calculated using the Hardy-Weinberg equation. The variation from the over-all mean is statistically significant $(P<0.001$, chi-square test); $95 \%$ confidence limits for the observed point frequencies are given in the table.

TABLE IV

$\alpha_{1}$-Acid Glycoprotein Gene Frequencies in Various Ethnic Groups

\begin{tabular}{|c|c|c|c|c|c|c|}
\hline \multirow[b]{2}{*}{ Ethnic group } & \multirow{2}{*}{$\begin{array}{l}\text { Total } \\
\text { number }\end{array}$} & \multicolumn{3}{|c|}{ Phenotypes } & \multicolumn{2}{|c|}{ Gene frequencies* } \\
\hline & & SS & FF & FS & Ors & Or \\
\hline Baka & 53 & 13 & 19 & 21 & $0.44(0.34-0.54) \ddagger$ & $0.56(0.46-0.65) \ddagger$ \\
\hline Bechuana & 61 & 26 & 11 & 24 & $0.62(0.53-0.71)$ & $0.38(0.29-0.47)$ \\
\hline Caucasian American & 220 & 27 & 89 & 104 & $0.36(0.32-0.40)$ & $0.64(0.60-0.68)$ \\
\hline Chinese & 73 & 15 & 19 & 39 & $0.47(0.38-0.56)$ & $0.53(0.43-0.62)$ \\
\hline Congolese & 45 & 13 & 16 & 16 & $0.47(0.36-0.58)$ & $0.53(0.42-0.64)$ \\
\hline Hungarian & 45 & 11 & 9 & 25 & $0.52(0.44-0.63)$ & $0.48(0.37-0.58)$ \\
\hline Finnish & 49 & 13 & 13 & 23 & $0.50(0.40-0.60)$ & $0.50(0.40-0.60)$ \\
\hline French & 39 & 11 & 12 & 16 & $0.49(0.37-0.60)$ & $0.51(0.39-0.63)$ \\
\hline Indian (Calcutta) & 50 & 8 & 14 & 28 & $0.44(0.34-0.54)$ & $0.56(0.46-0.66)$ \\
\hline Indian (Mexico) & 24 & 4 & 2 & 18 & $0.54(0.39-0.69)$ & $0.46(0.31-0.61)$ \\
\hline Japanese & 64 & 11 & 40 & 13 & $0.27(0.19-0.36)$ & $0.73(0.64-0.81)$ \\
\hline Mautsu & 35 & 12 & 9 & 14 & $0.54(0.42-0.67)$ & $0.46(0.33-0.58)$ \\
\hline Miozi & 13 & 3 & 5 & 5 & $0.42(0.23-0.63)$ & $0.58(0.37-0.76)$ \\
\hline Nigerian & 51 & 15 & 24 & 12 & $0.41(0.32-0.51)$ & $0.59(0.49-0.68)$ \\
\hline Nyambaan & 72 & 13 & 21 & 38 & $0.44(0.36-0.54)$ & $0.56(0.47-0.64)$ \\
\hline Pedi-S. Africa & 50 & 18 & 11 & 21 & $0.57(0.47-0.67)$ & $0.43(0.33-0.53)$ \\
\hline Pondo & 79 & 27 & 21 & 31 & $0.54(0.45-0.62)$ & $0.46(0.38-0.55)$ \\
\hline Shamgaam & 34 & 9 & 9 & 16 & $0.50(0.38-0.62)$ & $0.50(0.37-0.63)$ \\
\hline Swedish & 52 & 31 & 13 & 8 & $0.67(0.58-0.76)$ & $0.33(0.24-0.42)$ \\
\hline Ugandan & 30 & 7 & 17 & 6 & $0.33(0.22-0.46)$ & $0.67(0.53-0.78)$ \\
\hline Zulu & 67 & 15 & 33 & 19 & $0.37(0.28-0.46)$ & $0.63(0.54-0.72)$ \\
\hline Totals & 1206 & 302 & 407 & 497 & $0.46(0.43-0.48)$ & $0.54(0.53-0.56)$ \\
\hline
\end{tabular}

* The frequencies differed significantly among the groups $\left(P<0.001, x^{2}[20]\right)$. $\ddagger 95 \%$ confidence intervals for the observed point frequencies. 


\section{DISCUSSION}

In this investigation, small aliquots $(50 \mu \mathrm{l})$ of whole serum or plasma were treated with neuraminidase, and the $\alpha_{1}$-acid glycoprotein variants were then demonstrated by immunofixation after electrophoretic separation in standard gels. The simplicity of the technique, plus the small volume of blood required, facilitated the evaluation of types within families and in cord sera. Previous methods $(4,5)$ required $2.5-20 \mathrm{ml}$ of serum and at least partial purification of the protein before desialization.

As mentioned previously, the pattern of inheritance of the variants is that which would result from autosomal alleles $\left(O r^{m}\right.$ and $\left.O r^{s}\right)$ with codominant expression. However, the presence of both $\mathrm{F}$ and $\mathrm{S}$ bands in homozygous individuals suggests the possibility that both structural genes are present in all individuals and that the variant patterns are the result of genetically-determined variation in relative rates of synthesis of the proteins in the two bands. This assumption could also explain the intermediate patterns found in this study. Further evaluation of the variation in $F: S$ ratios is in progress.

The difference in electrophoretic mobility of the $\mathrm{F}$ and $\mathrm{S}$ bands is secondary to a difference in electrostatic net charge $(18,19)$. Although unequivocal differences in amino acid composition of the variant types have not been detected (18), it is probable that the electrostatic charge difference is the result of different amino acid compositions of the peptide chains of the two proteins, since the sialic acid-free carbohydrate units carry no net charge (31). Further clarification should come from amino acid sequence analysis.

Although transplacental passage of $\alpha_{1}$-acid glycoprotein is usually minimal, it has been suggested that sufficient maternal protein may cross the placenta to produce cord levels up to $20 \%$ of those in the maternal serum (32). The discordant types found in cord sera in the present study showed minimal if any contribution from maternal $\alpha_{1}$-acid glycoprotein as determined by antigenantibody crossed electrophoresis, even with the level in maternal serum as much as seven times greater than that in the cord serum.

The serum concentrations of $\alpha_{1}$-acid glycoprotein found in family members do not suggest genetic control of levels of this protein. A lack of correlation has been reported in identical twins (33).

\section{ACKNOWLEDGMENTS}

We are indebted to Doctors Henry Björling, Stockholm, Eva Vahvaselkä, Helsinki, J. M. Fine, Paris, and A. Zoutendyk, Johannesburg, for providing many of the serum samples used for determining gene frequencies. We are also grateful to Doctors Louis K. Diamond and Irving Umansky, Miss Lillian Watson, and Mrs. Helen Greitzer for critical review of the manuscript, and to Doctor Olli Miettinen for his help in the statistical analysis.

This study was supported in part by grants HD-02723, GM-10374, and 1-K3-GM-32,160 from the U. S. Public Health Service. Dr. A. Myron Johnson is the recipient of Special Fellowship 5-FO3-AM-39,593 from the U. S. Public Health Service.

\section{REFERENCES}

1. Schmid, K. 1953. Preparation and properties of serum and plasma proteins. XXIX. Separation from human plasma of polysaccharides, peptides and proteins of low molecular weight. Crystallization of an acid glycoprotein. J. Amer. Chem. Soc. 75: 60.

2. Weimer, H. E., J. W. Mehl, and R. J. Winzler. 1950. Studies on the mucoproteins of human plasma. V. Isolation and characterization of a homogeneous mucoprotein. J. Biol. Chem. 185: 561.

3. Schmid, K., J. P. Binette, K. Tokita, L. Moroz, and H. Yoshizaki. 1964. The polymorphic forms of $\alpha_{1}$-acid glycoprotein of normal Caucasian individuals. J. Clin. Invest. 43: 2347.

4. Schmid, K., K. Tokita, and H. Yoshizaki. 1965. The $\alpha_{1}$-acid glycoprotein variants of normal caucasian and Japanese individuals. J. Clin. Invest. 44: 1394.

5. Hunziker, K., and K. Schmid. 1967. A brief method for the identification of the $\alpha_{1}$-acid glycoprotein variants. Anal. Biochem. 20: 495.

6. Tokita, K., J. F. Burke, H. Yoshizaki, S. Fischer, and K. Schmid. 1966. The constancy of the $\alpha_{1}$-acid glycoprotein variants of normal adults under conditions of severe stress. J. Clin. Invest. 45: 1624.

7. Schmid, K., R. A. Field, and H. Yoshizaki. 1968. Constancy of $\alpha_{1}$-acid glycoprotein variants of caucasian patients under conditions of severe stress. J. Med. Genet. 5: 36.

8. Schultze, H. E., K. Heide, and H. Haupt. 1962. Die mit Perchlorsäure nicht fällbaren Proteine des Humanserums. Clin. Chim. Acta. 7: 854.

9. Scheidegger, J. J. 1955. Une micro-méthode de l'immunoélectrophorèse. Intern. Arch. Allergy Appl. Immunol. $7: 103$.

10. Laurell, C.-B., and J.-E. Niléhn. 1966. A new type of inherited serum albumin anomaly. J. Clin. Invest. 45: 1935.

11. Propp, R. P., and C. A. Alper. 1968. C'3 synthesis in the human fetus and lack of transplacental passage. Science (Washington). 162: 672.

12. Alper, C. A., and R. P. Propp. 1968. Genetic polymorphism of the third component of human complement (C'3). J. Clin. Invest. 47: 2181.

13. Smithies, O. 1959. An improved procedure for starchgel electrophoresis: further variations in the serum proteins of normal individuals. Biochem. J. 71: 585 .

14. Alper, C. A., and A. M. Johnson. 1969. Immunofixation electrophoresis: a technique for the study of protein polymorphism. Vox Sang. 17: 445.

15. Uriel, J. 1966. Méthode d'électrophorèse dans des gels d'acrylamide-agarose. Bull. Soc. Chim. Biol. 48: 969.

16. Laurell, C.-B. 1965. Antigen-antibody crossed electrophoresis. Anal. Biochem. 10: 358.

17. Laurell, C.-B. 1966. Quantitative estimation of proteins by electrophoresis in agarose gel containing antibodies. Anal. Biochem. 15: 45. 
18. Schmid, K., A. Polis, K. Hunziker, R. Fricke, and $M$. Yayoshi. 1967. Partial characterization of the sialic acid-free forms of $\alpha_{1}$-acid glycoprotein from human plasma. Biochem. J. 104: 361.

19. Schmid, K., T. Okuyama, and H. Kaufman. 1968. Isolation and chemical composition of the human plasma $\alpha_{1}$-acid glycoprotein variants. Biochim. Biophys. Acta. 154: 565.

20. Laurell, C.-B. Electrophoretic microheterogeneity of serum $\alpha_{1}$-antitrypsin. Scand. J. Clin. Lab. Invest. 17: 271.

21. Shreffler, D. C., G. J. Brewer, J. C. Gall, and M. S. Honeyman. 1967. Electrophoretic variation in human serum ceruloplasmin: a new genetic polymorphism. Biochem. Genet. 1: 101.

22. Poulik, M. D. 1968. Heterogeneity and structure of ceruloplasmin. Ann. N. Y. Acad. Sci. 151: 476.

23. Boyer, S. H., and W. J. Young. 1960. $\beta$-globulin polymorphism in chimpanzees. Nature (London). 187: 1035.

24. Harris, H., D. G. Penington, E. B. Robson, and C. R. Scriver. 1960. A further genetically determined transferrin variant in man. Ann. Human Genet. 24: 327.

25. Axelsson, U., and C.-B. Laurell. 1965. Hereditary variants of serum $\alpha_{1}$-antitrypsin. Amer. J. Human Genet. 17: 466.

26. Laurell, C.-B. 1968. Orosomucoid and $\alpha_{1}$-antitrypsin in maternal and fetal sera at parturition. Scand. J. Clin. Lab. Invest. 21: 136.

27. Cleve, H., R. L. Kirk, W. C. Parker, A. G. Bearn, L. E. Schact, H. Kleinman, and W. R. Horsfall. 1963. Two genetic variants of the group-specific component of human serum: Gc Chippewa and Gc Aborigine. Amer. J. Human Genet. 15: 368.

28. Reinskou, T. 1965. A new variant in the Gc system. Acta Genet. Statist. Med. (Basel). 15: 248.

29. Parker, W. C., and A. G. Bearn. 1963. Control gene mutations in the human haptoglobin system. Nature (London). 198: 107.

30. Alper, C. A., and F. S. Rosen. 1969. A hyposynthetic genetic variant of human $\mathrm{C}^{\prime} 3 \mathrm{~F}$. J. Clin. Invest. 47: $2 a$. (Abstr.)

31. Heimburger, N., K. Heide, H. Haupt, and H. E. Schultze. 1964. Bausteinanalysen von Humanserumproteinen. Clin. Chim. Acta. 10: 293.

32. Gitlin, D., J. Kumate, J. Urrusti, and C. Morales. 1964. The selectivity of the human placenta in the transfer of plasma proteins from mother to fetus. J. Clin. Invest. 43: 1938.

33. Störiko, K. 1968. Normal values for 23 different human plasma proteins determined by single radial immunodiffusion. Blut. 16: 200. 